\title{
DAMPAK KEHIDUPAN SOSIAL DAN EKONOMI PEMBANGUNAN KAMPUNG INGGRIS KEBUMEN (KIK) (STUDI KASUS PADA MASYARAKAT DESA JATIJAJAR, KECAMATAN AYAH, KABUPATEN KEBUMEN)
}

\author{
Wahyu Misniawati dan V. Indah Sri Pinasti Fakultas \\ IImu Sosial, Universitas Negeri Yogyakarta Email : \\ Wahyumisniawati@gmail.com
}

\begin{abstract}
Abstrak
Penelitian ini bertujuan untuk mengetahui dampak kehidupan sosial dan ekonomi pada masyarakat Desa Jatijajar akibat adanya pembangunan Kampung Inggris Kebumen di Desa Jatijajar sebagai pusat pembelajaran percakapan bahasa Inggris. Penelitian dilakukan dengan menggunakan metode kualitatif deskriptif. Informan penelitian dipilih menggunakan metode purposive sampling. Teknik pengumpulan data dilakukan dengan observasi, wawancara, dan dokumentasi. Teknik validasi data menggunakan metode triangulasi, sedangkan Proses analisis data dalam penelitian ini menggunakan metode analisis Miles dan Huberman yang terdiri dari tahap pengumpulan data, reduksi data, penyajian data dan penarikan kesimpulan. Hasil penelitian ini menunjukan bahwa dalam pelaksanaan pembangunan KIK membawa perubahan yang berdampak pada kehidupan sosial dan ekonomi masyarakat Desa Jatijajar. Dampak di bidang ekonomi yaitu terciptanya lapangan pekerjaan baru, dan peningkatan penghasilan masyarakat melalui berbagai sektor ekonomi berupa homestay, laundry, katering, dan warung. Dampak sosial pada masyarakat berupa perubahan status sosial, berubahnya pola interaksi masyarakat, peningkatan kemampuan berbahasa Inggris, perubahan pola penggunaan bahasa, serta terbentuknya lembaga sosial baru. Masyarakat juga merasakan dampak negatif dari pembangunan KIK berupa kebisingan serta tidak meratanya partisipasi masyarakat.
\end{abstract}

Kata kunci: pembangunan, Kampung Inggris Kebumen (KIK), dampak sosial, dampak ekonomi

\section{Abstract}

This study aims to determine the impact of social and economic life on the Jatijajar Village community due to the development of Kebumen English Village (KIK) which makes Jatijajar Village the center of English conversation learning in Kebumen District. This research uses descriptive qualitative methods. The informants were selected using a purposive sampling method. Data collection techniques were carried out by observation, interviews, and documentation. Data validation techniques using the triangulation methods. The process of data analysis uses the Miles and Huberman analysis method which consists of data collection, data reduction, data presentation, and the process of drawing conclusions. The results of this study indicate that the implementation of KIK development has brought an impact on the social and economic life of the Jatijajar Village community. The impact in the economic field is the creation of new jobs, and the increase of people's income through various economic sectors in the form of homestays, laundry, catering, and stalls. Whereas the social impact felt by the community in the form of changes in social status, changing patterns of community

interaction, improving English language use and the formation of new social skills, changing patterns of language institutions. The community also felt the 
negative impact of the KIK development in the form of noise and the unbalance distribution of community participation.

Keywords: development, Kebumen English Village (KIK), social impact, economic impact

\section{Pendahuluan}

Setiap manusia memiliki keinginan untuk selalu berkembang, maju, dan berubah menjadi lebih baik dalam kehidupannya. Oleh karena itu kehidupan masyarakat bersifat dinamis dan selalu mengalami perubahan. Pembangunan merupakan salah satu bentuk perubahan sosial yang sengaja dilakukan oleh masyarakat dengan tujuan-tujuan untuk meningkatkan taraf hidup masyarakat. Adanya pembangunan merupakan cerminan masyarakat yang ingin berubah untuk mencapai standar kehidupan yang layak. Pembangunan pada dasarnya adalah suatu proses transformasi masyarakat dari suatu keadaan menuju ke keadaan lain yang semakin mendekati tatanan masyarakat yang dicita-citakan. Pembangunan merupakan suatu bentuk perubahan sosial yang disengaja dengan tujuan untuk memajukan masyarakat. Fokus utama dimensi sosial dalam pembangunan melibatkan suatu proses perubahan sistem, struktur, dan nilai sosial suatu masyarakat.
Elemen sosial, termasuk aspek nilai dipercayai memiliki hubungan langsung dengan proses pembangunan (Hatu, 2013). Salah satu yang menjadi fokus utama pembangunan daerah-daerah di Indonesia adalah pembangunan pedesaan, hal ini disebabkan sebagian besar wilayah Indonesia masih berupa pedesaan. Pembangunan untuk meningkatkan pelayanan sosial pedesaan, seperti pendidikan, secara langsung berkaitan dengan usaha peningkatan mutu hidup penduduk pedesaan (Zuhal, 2008). Berkaitan dengan pembangunan daerah, Indonesia menggunakan sistem desentralisasi dengan memberikan otonomi kepada daerah. Otonomi daerah memberikan otoritas yang lebih besar kepada pemerintah daerah (kota dan kabupaten) dalam menyelenggarakan pemerintahan dan mengelola keuangan. Bidang-bidang yang dapat diserahkan kepada pemerintah deaerah antara lain: pendidikan, pekerjaan umum, kesehatan, pertanian, perhubungan, industri dan perdagangan, penanaman modal, lingkungan hidup, koperasi, dan tenaga kerja.

$\begin{array}{rrr}\text { Kampung } & \text { Inggris } & \text { Kebumen } \\ (\mathrm{KIK}) \text { adalah } & \text { sebuah } & \text { program }\end{array}$


pembangunan daerah yang didirikan oleh pemerintah daerah Kabupaten Kebumen pada tanggal 9 Agustus 2016. KIK terletak di Desa Jatijajar, Kecamatan Ayah, Kabupaten Kebumen. KIK didirikan dengan tujuan untuk meningkatkan kualitas sumber daya manusia dalam penguasaan bahasa Inggris. Dalam pelaksanaannya PEMDA Kebumen bekerja sama dengan salah satu lembaga kursus bahasa Inggris yang berasal dari Pare, Kabupaten Kediri yaitu FEE Center untuk menjalankan program KIK dimana struktur pembelajarannya juga diadopsi dari sistem-sistem pembelajaran yang dilakukan oleh beberapa lembaga kursus bahasa Inggris di Pare, Kediri yang telah sukses menjadikan Pare sebagai Kampung Inggris yang tersohor hingga ke mancanegara. Pembangunan Kampung Inggris Kebumen (KIK) telah mendatangkan banyak pendatang baru dari berbagai daerah untuk menimba ilmu di desa tersebut sehingga rutinitas sehari-hari Desa Jatijajar pun menjadi berbeda dibandingkan sebelum menjadi Kampung Inggris Kebumen (KIK). Perubahan-perubahan yang terjadi akibat hal tersebut mencakup seluruh aspek kehidupan masyarakat Desa Jatijajar, mulai dari perubahan sistem sosial, sistem ekonomi, kebiasaan masyarakat, hingga perubahan penggunaan bahasa. Adanya perubahan sosial tersebut akan mempengaruhi pula sistem sosial masyarakat Desa Jatijajar termasuk didalamnya adalah adanya perubahan nilai-nilai, sikap, dan pola perilaku.

Setiap kebijakan pembangunan yang dilakukan pemerintah di berbagai bidang memiliki tujuan baik secara langsung maupun tidak langsung kepada peningkatan kegiatan perekonomian masyarakat. Perubahan di bidang ekonomi antara lain adanya perubahan pada jenis mata pencaharian, perluasan lapangan pekerjaan, tingkat kesejahteraan ekonomi masyarakat. Pembangunan juga dapat berdampak pada kehidupan sosial masyarakat dimana pembangunan baik secara langsung maupun tidak langsung akan membawa perubahan sosial. Perubahan bidang sosial akibat adanya pembangunan dapat mencakup perubahan cara berpikir dan perilaku yang lebih rasional dan perubahan pada pola-pola hubungan dalam masyarakat sehingga mempengaruhi sistem sosial masyarakat yang sudah ada sebelumnya (Syahrial, 2016). 
Penelitian ini dilakukan untuk mengetahui bagaimana bentuk pembangunan yang terjadi di Kampung Inggris Kebumen (KIK), serta bagaimana dampak pembangunan KIK tersebut terhadap kehidupan sosial dan ekonomi masyarakat Desa Jatijajar.

\section{Metode}

Penelitian ini menggunakan pendekatan kualitatif deskriptif. Kualitatif deskriptif merupakan penelitian yang memberikan gambaran secara cermat mengenai individu atau kelompok tertentu tentang keadaan dan gejala yang terjadi. Lokasi penelitian yang dilakukan bertempat di Desa Jatijajar, Kecamatan Ayah, Kabupaten Kebumen, Jawa Tengah. Alasan pemilihan lokasi ini dikarenakan desa tersebut telah dijadikan sebagai Kampung Inggris Kebumen (KIK) yang berfungsi sebagai pusat studi bahasa Inggris di Kabupaten Kebumen. Waktu penelitian dilakukan selama kurang lebih dua bulan, yaitu pada bulan Juni hingga bulan Juli tahun 2018. Teknik sampling yang digunakan untuk menentukan subjek penelitian dalam penelitian ini adalah purposive sampling. Adapun jenis Informan yang dipilih serta memenuhi kriteria-kriteria penelitian antara lain; Kepala Desa Jatijajar, pengurus organisasi Kampung Inggris Kebumen, tutor Kampung Inggris Kebumen, warga pemilik homestay, warga pemilik warung dan rumah makan, warga pemilik usaha katering, warga yang menerima jasa laundry, Warga Desa Jatijajar biasa atau masyarakat umum. Jenis data dalam penelitian ini berupa data primer dan data sekunder, data primer diperoleh melalui wawancara dan observasi secara langsung serta dokumentasi, sedangkan data sekunder diperoleh melalui data-data yang diambil dari lembaga-lembaga terkait seperti kantor kepala desa dan kantor sekretariat KIK.

Teknik pengumpulan datanya menggunakan tiga macam cara yaitu; observasi, wawancara dan dokumentasi. observasi dilakukan dengan mengamati secara langsung kehidupan dan interaksi sehari-hari masyarakat Desa Jatijajar berkaitan dengan kegiatan KIK, serta kegiatankegiatan yang dilakukan di KIK. Wawancara dilakukan peneliti kepada narasumber atau informan yang telah terlebih dahulu dipilih melalui teknik purposive sampling dimana informan terpilih merupakan orang-orang yang mengetahui, 
berkontribusi, serta mendapatkan dampak di bidang ekonomi dan sosial sebagai akibat dari adanya pembangunan KIK di Desa Jatijajar. gambar, tulisan, atau karya-karya monumental dari seseorang. Dokumentasi dilakukan dengan mengambil gambar proses penelitian, serta data-data monografi atau dokumen resmi baik mengenai Desa Jatijajar maupun mengenai Kampung Inggris Kebumen yang penulis peroleh dari lembaga-lembaga terkait. Teknik analisis data dalam penelitian ini menggunakan metode interaktif Miles dan Huberman untuk menganalisis data dari hasil penelitian yang dilakukan, yang tahapannya terdiri dari:

1. Pengumpulan data

Dalam penelitian ini pengumpulan data diperoleh dari hasil pengamatan lingkungan serta kondisi sosial Desa Jatijajar, serta melakukakan wawancara dengan narasumber yang telah ditentukan sebelumnya. Dokumentasi juga dilakukan selama proses pengumpulan data yang dapat digunakan sebagai bukti penelitian. Selain itu pengumpulan data sekunder diperoleh melalui data-data di balai Desa Jatijajar, sekretariat KIK, dan sumber resmi lainnya.

2. Reduksi data

Reduksi data merupakan kegiatan merangkum kembali catatancatatan yang diperoleh di lapangan dengan memilih hal-hal yang pokok dan difokuskan kepada hal-hal yang penting yang berhubungan dengan tema penelitian ini. Pada tahap ini, peneliti akan melakukan penyederhanaan data melalui proses koding, dan memilih data-data yang sekiranya penting, dan data-data yang tidak sesuai dengan topik penelitian ini.

\section{Penyajian data}

Pada tahap penyajian data, peneliti melakukan analisis terhadap data-data yang sudah didapatkan di lapangan berkaitan dengan tema penelitian yang dilakukan mengenai bentuk pembangunan yang terjadi di Desa Jatijajar berupa Kampung Inggris Kebumen, serta dampaknya di bidang ekonomi dan bidang sosial bagi masyarakat Desa Jatijajar dan sekitarnya.

4. Penarikan kesimpulan

Pada tahap penarikan kesimpulan, peneliti meringkas hasil observasi dan wawancara yang telah dianalisis dalam penyajian data. Hal 
ini dilakukan untuk mempersempit hasil analisis tersebut dan memilih yang sesuai dengan rumusan masalah yang telah dibuat di awal penelitian.

\section{Hasil dan Pembahasan}

\section{a. Kebijakan Pembangunan KIK}

Pembentukan Kampung Inggris Kebumen berawal dari ide Bupati Kebumen Ir. H. Mohammad Yahya Fuad, SE yang menghendaki adanya kesiapan sumber daya manusia di Kabupaten Kebumen dalam menyongsong era global yang ditandai telah dimulainya (Masyarakat Ekonomi ASEAN) MEA. KIK didirikan pada tanggal 9 Agustur 206 dengan visi misi KIK adalah sebagai berikut:

Visi: Menjadi pusat
pembelajaran percakapan bahasa
Inggris kelas dunia yang berpilar pada
keimanan, ketakwaan, sosial dan
budaya.

Misi: Melayani masyarakat dalam dan luar Kabupaten Kebumen untuk berlatih menguasai percakapan bahasa Inggris dalam waktu yang singkat, seraya memperkuat nilai-nilai keimanan, ketakwaan, kemasyarakatan, dan jatidiri budaya serta bangsa Indonesia.

Pembangunan Kampung Inggris Kebumen berdasarkan pada peraturan otonomi daerah seperti yang tertuang dalam Undang-Undang nomor 22 tahun 1999 tentang otonomi daerah. Otonomi daerah merupakan pemberian kewenangan kepada pemerintah daerah baik kabupaten/kota untuk mengatur urusan rumah tangganya sendiri. Otonomi daerah memungkinkan daerah untuk merencanakan dan melaksanakan pembangunan daerahnya sendiri demi kepentingan daerah tersebut yang berdasarkan pada potensi dan kebutuhan daerah masing-masing.

Kebijakan pembangunan KIK sejalan dengan visi dan misi pembangunan daerah Kabupaten Kebumen yang tertuang dalam Peraturan Daerah Kabupaten Kebumen No.6 tahun 2016 tentang Rencana Pembangunan Jangka Menengah Daerah (RPJMD) poin 1 dan 2 yaitu;

a. Membangun sumber daya manusia yang memiliki wawasan luas, tangguh serta berkemajuan melalui pendidikan dan kesehatan yang berkualitas

b. Peningkatan kesejahteraan dan perlindungan sosial masyarakat dengan melakukan pemerataan dan penyeimbangan pembangunan secara 
berkelanjutan untuk mengurangi kesenjangan ekonomi, sosial, politik dan budaya.

\section{Berdasarkan}

rencana

pembangunan daerah Kabupaten Kebumen yang tertuang dalam RPJMD tahun 2016-2021 di atas, pemerintah Kabupaten Kebumen yang mengatur mengenai pembentukan kampung bahasa yang tertuang dalam Peraturan Bupati Kebumen No. 71 Tahun 2017 Tentang Pedoman Pendirian Kampung Bahasa. Peraturan tersebut merupakan dasar hukum pembangunan Kampung Bahasa di Kabupaten Kebumen yang salah satunya adalah Kampung Inggris Kebumen yang terletak di Desa Jatijajar, Kecamatan Ayah.

\section{b. Kegiatan KIK}

Kegiatan yang ada di Kampung Inggris Kebumen (KIK) berupa pelatihan percakapan bahasa Inggris. Kursus yang dilakukan di KIK berjalan selama 14 hari atau 7 hari. Biaya yang diperlukan peserta untuk mengikuti pelatihan bahasa Inggris selama 14 hari di KIK yaitu sebesar Rp. 1.050.000, sedangkan untuk program 7 hari dikenakan biaya sebesar Rp. 600.000 .

Peserta pelatihan KIK berasal dari berbagai kalangan, baik itu jenjang sekolah dasar, SMP, SMA, Perguruan tinggi, ataupun masyarakat secara umum. Metode pembelajaran yang dilakukan yaitu menggunakan metode pembelajaran $4 \mathrm{M}$, yaitu; Mendengar, Meniru, Mengucapkan dan Mengulangi. Metode pembelajaran ini diadopsi dari metode pembelajaran yang digunakan oleh FEE Center (Future English Education Center) yang berasal dari Pare, Kabupaten Kediri.

Pembelajaran di KIK menekankan pada pemanfaatan bahasa Inggris secara praktis dalam kehidupan sehari-hari, sehingga lebih menekankan pada speaking dan conversations yang menuntun peserta agar lebih berani berbicara dalam bahasa Inggris. Karena lebih menekankan pada speaking, pengajaran yang dilakukan oleh tutor menggunakan cara "speaking loudly" atau berbicara dengan suara lantang, begitupun para peserta harus mengucapkan dengan suara yang lantang.

Pilar dasar yang digunakan sebagai dasar utama dalam pembelajaran KIK yaitu menjunjung tinggi nilai keimanan, ketakwaan, sosial dan budaya. Sehingga pembelajaran di KIK bukan saja pembelajaran yang menekankan 
pada kemampuan berbahasa Inggris namun juga adanya pembentukan karakter yang dibangun selama peserta mengikuti kegiatan pelatihan di KIK.. pembentukan karakter yang dilakukan di KIK meliputi kedisiplinan dalam hal waktu, memperkuat nilai keimanan dan ketakwaan dengan mendisiplinkan peserta pelatihan yang beragama Islam untuk sholat lima waktu secara berjamaah, serta memperkuat jiwa sosial dengan menjalin hubungan dengan masyarakat sekitar.

Diluar kegiatan pembelajaran yang dilakukan oleh peserta pelatihan, Tutor juga mengadakan kelas informal dengan anak-anak Desa Jatijajar yang ingin mempelajari bahasa Inggris, kelas ini diadakan secara gratis bagi anak-anak Desa Jatijajaryang dilakukan sebanyak 2-3 kali dalam satu minggu. Selain itu pembelajaran bahasa Inggris juga dilakukan oleh para orang tua. Pembelajaran yang dilakukan oleh orang tua tersebut dilaksanakan pada awal pembangunan KIK. Sebanyak 115 warga yang mengikuti pelatihan tersebut, dan dari pelatihan tersebut 93 orang telah mengikuti pelatihan hingga akhir dan mendapat sertifikat pelatihan. Peserta pelatihan tersebut terdiri dari berbagai macam kalangan, dan berbagai usia dan pekerjaan.

\section{c. KIK dalam Paradigma \\ Pembangunan Manusia}

Paradigma Pembangunan manusia berarti menjadikan manusia sebagai tujuan akhir pembangunan, bukan sebagai alat pembangunan. Pembangunan manusia menekankan pada terpenuhinya kehidupan yang layak bagi manusia. Pertumbuhan ekonomi dapat menunjang pemenuhan hak dan kebebasan, serta mempromosikan simbiosis antara pembangunan ekonomi dan keadilan sosial, antara ekonomi yang maju dan politik yang sehat, serta antara kesejahteraan masyarakat dan individu (Suparno, 2014).

Pengembangan sumber daya manusia merupakan faktor penting dalam pembangunan manusia. Pengembangan SDM dalam kaitannya dengan human-centered development bukan saja berarti untuk membentuk manusia profesional dan terampil untuk memberikan kontribusinya dalam proses pembangunan, namun lebih menekankan pada pentingnya "pemampuan" (empowerment) manusia (Tjokrowinoto, 2001, hal. 29). 
Menurut UNDP, (HDR, 1990) Pembangunan manusia merupakan suatu model pembangunan tentang penduduk, untuk penduduk dan oleh penduduk. Tentang penduduk berarti pembangunan dapat berupa investasi di bidang pendidikan, kesehatan, dan pelayanan sosial lainnya. Untuk penduduk dapat berupa penciptaan peluang kerja melalui perluasan (pertumbuhan) ekonomi. Oleh penduduk yaitu berupa upaya pemberdayaan (empowerment) penduduk dalam menentukan harkat manusia dengan cara berpartisipasi dalam pembangunan. Pembangunan manusia memiliki 4 (empat) komponen esensial seperti yang dikemukakan oleh (Jamaludin, 2016) yaitu terdiri dari; kesetaraan, produktivitas, pemberdayaan, dan keberlanjutan.

Pertama, kesetaraan berarti merujuk pada kesamaan akses ke sumber daya ekonomi dan politik yang menjadi hak dasar warga negara. Hal ini berarti adanya akses terhadap kesempatan yang merata kepada kesempatan ekonomi dan politik. Pembangunan KIK memiliki sifat kesetaraan dilihat dari luasnya kesempatan masyarakat untuk ikut serta dalam kegiatan pelatihan dimana pelatihan atau kursus bahasa
Inggris yang diadakan di KIK terbuka bagi setiap kalangan baik itu usia sekolah, SD, SMP, SMA, Perguruan Tinggi atau masyarakat umum memiliki hak dan kewajiban yang sama untuk dapat menjadi peserta pelatihan di KIK.

Kedua, produktivitas merujuk pada usaha-usaha sistematis yang bertujuan meningkatkan kegiatan ekonomi. Yaitu peningkatan kapabilitas sumber daya manusia melalui investment in people agar potensial maksimal mereka dapat digunakan sebagai sarana untuk mencapai pertumbuhan. Peningkatan SDM melalui investment in people dalam KIK yaitu dengan adanya pelatihan bahasa Inggris di KIK diharapkan mampu meningkatkan kualitas bahasa Inggris peserta pelatihan yang dapat meningkatkan daya saing SDM di Kabupaten Kebumen khususnya agar dapat bersaing di kancah internasional di era global saat ini.

Ketiga, Pemberdayaan atau empowerment dimaksudkan pada pembangunan berdasarkan partisipasi penuh masyarakat, yaitu masyarakat bukan hanya sebagai penerima, melainkan juga aktif dalam menentukan pilihan mengenai cara hidup mereka sendiri. Pemberdayaan 
masyarakat dalam pembangunan KIK dapat dilihat dari peran aktif masyarakat dalam setiap tahap pembangunan KIK dari mulai perencanaan, pelaksanaan, hingga evaluasi. Pembangunan KIK juga memberdayakan masyarakat agar dapat berperan aktif, serta dapat mengambil peluang usaha dari adanya KIK tersebut.

Keempat, yaitu keberlanjutan atau sustainability. Keberlanjutan dimaksudkan bahwa tingkat kesejahteraan yang dinikmati masa kini harus bisa dinikmati oleh generasi yang akan datang. Jelas bahwa tujuan pembangunan KIK dimaksudkan sebagai sarana peningkatan kualitas SDM Kabupaten Kebumen agar memiliki daya saing yang tinggi ini bersifat sustainbility atau keberlanjutan. Pembangunan pendidikan dalam wujud pembanguan KIK di Desa Jatijajar ini merupakan investasi yang dilakukan oleh pemerintah Kabupaten Kebumen dalam meningkatkan kualitas modal manusia yang manfaatnya diharapkan dapat terus dinikmati oleh generasi saat ini ataupun generasi yang akan datang secara terus menerus.

\section{d. Dampak Pembangunan KIK}

Dalam teori struktural fungsional, masyarakat dibaratkan sebagai organisme hidup, dimana masyarakat selalu mengalami pertumbuhan layaknya organisme hidup. Dalam premis ini, diibaratkan bahwa setiap bagian baik dalam organisme hidup maupun masyarakat saling berkaitan satu sama lain dan memiliki fungsi dan tujuan tertentu dimana perubahan yang terjadi pada satu bagian dapat berpengaruh pada bagian yang lainnya juga (Poloma, 2013).

Pembangunan dan perubahan sosial merupakan dua hal yang tidak dapat dipisahkan. Pembangunan yang terjadi dan yang sedang diupayakan membawa adanya perubahan baik perubahan yang dikehendaki maupun perubahan yang tidak dikehendaki.

Adanya pembangunan $\mathrm{KIK}$ di Desa Jatijajar menyebabkan adanya perubahan di bidang lain sebagai akibat dari pembangunan tersebut dalam masyarakat, termasuk juga perubahan di bidang sosial dan ekonomi yang tidak dapat dihindari. Hal ini sesuai dengan pandangan struktural fungsional bahwa perubahan dalam suatu bidang akan menyebabkan perubahan pada bidang lain juga dimana bidang- 
bidang tersebut saling mempengaruhi secara timbal balik. Adapun perubahan di bidang sosial dan ekonomi yang dirasakan oleh masyarakat Desa Jatijajar akibat adannya pembangunan KIK adalah sebagai berikut:

\section{1) Dampak ekonomi}

Indikator dampak ekonomi yang dikaji dalam penelitian ini meliputi; munculnya lapangan pekerjaan baru, mengurangi pengangguran, serta adanya tambahan penghasilan dari berbagai lapangan pekerjaan baru sehingga dapat meningkatkan kesejahteraan masyarakat Desa Jatijajar. Dampak ekonomi adanya KIK antara lain:

a) Lapangan pekerjaan sebagai tutor Pembangunan Kampung Inggris Kebumen bukan hanya sebagai media peningkatan kualitas sumber daya manusia dalam berbahasa Inggris, tetapi juga memberdayakan serta memberikan lapangan pekerjaan bagi warga Desa Jatijajar itu sendiri maupun warga sekitarnya sehingga KIK bukan hanya bermanfaat bagi peserta pelatihan bahasa Inggris saja namun juga bermanfaat bagi warga sekitar.

Dalam tahap sosialisasi KIK yang dilakukan pemerintah Kabupaten Kebumen kepada warga
Desa Jatijajar, dilakukan pula seleksi calon tutor KIK. Calon Tutor KIK adalah mereka yang berminat menjadi tutor pengajar bahasa Inggris di KIK dan bersedia mengikuti pelatihan tutor yang dilaksanakan di lembaga kursus bahasa Inggris yaitu FEE Center.

Tutor yang terpilih dalam tahap seleksi selanjutnya dibiayai oleh pemerintah untuk belajar terlebih dahulu selama 1,5 tahun di FEE Center, dan setelah kembali mere diberikan pekerjaan sebagai tutor pengajar di KIK. Lapangan pekerjaan sebagai tutor ini telah memberikan warga masyarakat kesempatan dan peluang pekerjaan sehingga mengurangi jumlah pengangguran baik di Desa Jatijajar maupun desa sekitarnya. Hal ini dikarenakan tutor tersebut dipilih dari warga Desa Jatijajar dan sekitarnya.

b) Lapangan pekerjaan sebagai pemilik homestay

Homestay atau penginapan yang ada di KIK merupakan rumahrumah warga yang dijadikan sebagai tempat tinggal sementara untuk para peserta pelatihan. Hingga saat ini total ada 30 homestay yang siap untuk ditempati di KIK yang dapat menampung kurang lebih 200 peserta pelatihan. 
Rumah warga yang menjadi homestay telah melalui seleksi kelayakan yang telah dilakukan oleh pengurus KIK. Seleksi tersebut meliputi kebersihan rumah dan kebersihan kamar, fasilitas kamar, fasilitas MCK yang memadai, fentilasi yang cukup dan lain sebagainya. Pemerikasaan kelayakan homestay tidak hanya dilakukan sekali, namun dilakukan secara berkala, pemerikasaan dilakukan oleh pengurus KIK untuk memeriksa kebersihan homestay serta kelengkapan homestay yang ada

Penghasilan yang mereka dapatkan untuk program 2 minggu sebesar Rp 125.00 sedangkan untuk program 1 minggu sebesar Rp 75.000 untuk setiap anak yang menginap di homestay mereka. Biaya tersebut sudah termasuk kedalam biaya listrik dan juga biaya air. Dengan penghasilan yang mereka dapatkan dari homestay, para pemilik merasa senang meskipun hasilnya tidak banyak namun cukup digunakan untuk tambahan penghasilan, dan dapat memenuhi kebutuhan seharihari mereka.

c) Peningkatan penghasilan dari usaha katering dan laundry

Untuk memenuhi kebutuhan konsumsi peserta pelatihan,
Pengurus KIK menyediakan akomodasi makanan sebanyak tiga kali sehari dalam bentuk prasmanan. Makanan tersebut disediakan dan dimasak oleh warga sekitar. katering dilakukan oleh warga lain yang rumahnya berada di sekitar homestay atau kelas sebagai penyedia jasa katering.

Seluruh katering yang disediakan warga nantinya akan dibayarkan oleh pengurus KIK menggunakan biaya pendaftaran para peserta pelatihan. Biasanya rumah yang memiliki usaha katering tidak dilakukan sendiri, melainkan mengajak tetangga mereka untuk membantu memasakkan menu makanan. Usaha katering ini bukan saja menguntungkan pemilik katering namun juga tetangga sekitar yang ikut bekerja membantu menyiapkan katering, karena mereka juga mendapat penghasilan dari usaha tersebut.

Untuk memenuhi kebutuhan laundry peserta, Pengurus juga memberikan peluang tersebut kepada masyarakat sekitar. Biasanya laundry juga dilakukan oleh pemilik homestay, namun banyak juga homestay yang tidak sanggup menerima laundry sehingga memberikan kesempatan tersebut kepada masyarakat sekitar. 
Sebuah usaha laundry di KIK adanya pembangunan KIK juga biasanya mendapat bagian untuk memunculkan dampak negatif. mencuci pakaian di beberapa Dampak negatif tersebut berupa homestay yang dekat dengan lokasi ppartisipasi masyarakat yang tidak mereka. Para peserta pelatihan merata. Hal ini ditunjukan bahwa mendapat jatah laundry sebanyak 2 seorang warga bisa mendapatkan potong pakaian setiap harinya. Warga penghasilan tambahan dari homestay, yang menerima laundry dari para dan dari katering atau laundry secara peserta pelatihan ini kebanyakan sekaligus. Sedangkan disisi lain, ada adalah ibu rumah tangga yang tidak bekerja atau hanya mengurus rumah dan anaknya sehingga kegiatan laundry ini dapat digunakan untuk mengisi waktu luang warga dan mendapatkan tambahan penghasilan dari usaha laundry tersebut.

d) Peningkatan penghasilan melalui usaha warung

Warga yang memliki usaha warung kelontong yang letaknya di sekitar homestay merasakan adanya dampak dari Kampung Inggris Kebumen, mereka mendapatkan tambahan penghasilan dari semakin banyaknya pembeli yang membeli berbagai macam barang di warung mereka. Semakin ramainya pembeli tersebut berasal dari peserta pelatihan dan juga dari tutor dan pengurus KIK.

e) Tidak meratanya partisipasi masyarakat

Selain mendatangkan banyak dampak positif di bidang ekonomi, warga yang tidak merasakan adanya dampak ekonomi adanya pembangunan KIK tersebut. Adanya ketidak merataan partisipasi masyarakat ini menyebabkan perbedaan penghasilan antara warga yang satu dengan warga yang lainnya.

\section{2) Dampak sosial}

Dampak pembangunan KIK bagi masyarakat Desa Jatijajar dalam bidang sosial dapat dilihat dari bebagai indikator sosial yang ada yang berupa berubahan pada dimensidimensi sosial dalam masyarakat. Indikator-indikator tersebut meliputi; perubahan pada dimesi struktural, dimensi kultural serta dimensi interaksional. Adapun dampak sosial yang dirasakan warga Desa Jatijajar antara lain:

a) Perubahan status sosial

Pembangunan KIK di Desa Jatijajar telah membawa perubahan pada struktur sosial masyarakat. 
Sebelum adanya pembangunan KIK, masyarakat Desa Jatijajar merupakan masyarakat desa pada umumnya yang struktur sosialnya mengacu pada adat istiadat. Mata pencaharian mayoritas di Desa Jatijajar adalah sebagai petani dan buruh tani, sedangkan masyarakat lain berprofesi sebagai buruh harian lepas, pedagang, PNS, dan lain sebagainya. Pembangunan KIK telah memunculkan peluang usaha baru berupa profesi menjadi tutor $\mathrm{KIK}$, menjadi pemilik homestay, laundry ataupun katering.

b) Perubahan pola interaksi

Dalam dimensi interaksional, hubungan antar masyarakat di Desa Jatijajar juga mengalami perubahan sebagai dampak dibangunnya KIK di desa mereka. Jika sebelum dibangunnya KIK interaksi masyarakat hanya sebatas interaksi dengan sesama warga, kini setelah didirikannya KIK interaksi yang terjalin di Desa Jatijajar menjadi semakin berkembang. Adanya pendatang yang berasal dari berbagai daerah sebagai peserta pelatihan bahasa Inggris di KIK menetap selama kurun waktu tertentu yang menyebabkan terjalinnya interaksi dengan warga masyarakat sekitar, selain itu interaksi juga terjalin antara tutor dan pengurus KIK dengan warga masyarakat.

Dalam kegiatan sehari-hari di KIK yang menjalin hubungan komunikasi paling intens adalah antara tutor dan juga peserta pelatihan, Mereka bertemu setiap hari untuk melakukan kegiatan pembelajaran. Dari hasil penelitan interaksi yang terjalin antara tutor dan peserta pelatihan nampak sangat baik dan dekat. Tutor dan peserta pelatihan berinteraksi hampir 24 jam, hal ini dikarenakan tutor bertanggung jawab mengawasi kegiatan pembelajaran serta kegiatan lainnya agar para peserta pelatihan menjadi lebih disiplin terhadap jadwal yang telah disusun. Tutor tidak hanya bertugas mengajar bahasa Inggris saja namun juga mengawasi peserta pelatihan, membangunkan peserta pelatihan setiap pagi, mengingatkan jadwal peserta pelatihan baik itu jadwal pembelajaran, jadwal sholat, waktu makan dan lain sebagainya hingga memerikasa keadaan setiap peserta pelatihan dan mengunjungi setiap homestay yang ditempati peserta pelatihan.

Interaksi peserta pelatihan dengan masyarakat sekitar terjalin karena peserta pelatihan hidup dan tinggal di sekitar masyarakat. Mereka 
tinggal di rumah warga yang dijadikan homestay. Peserta pelatihan menjalin hubungan baik dengan masyarakat hal ini terlihat dari sikap peserta pelatihan yang sering menyapa warga masyarakat apabila berpapasan dengan mereka di jalan.

Tutor dan masyarakat sekitar juga menjalin interaksi, mereka berhubungan langsung dengan masyarakat KIK. Hubungan dengan masyarakat juga ditandai dengan adanya koordinasi antar pengurus dan masyarakat baik dalam urusan pembagian homestay, pembagian katering dan laundry, keduanya juga melakukan koordinasi untuk mengawasi dan menjaga para peserta pelatihan. Interaksi juga terjalin antara tutor dan pemilik homestay karena sering bertemu dan bertutur sapa satu sama lain.

c) Peningkatan kemampuan bahasa Inggris

Dalam tahap persiapan pembangunan KIK ada 115 warga Desa Jatijajar telah mendapatkan pelatihan bahasa Inggris. Warga tersebut berasal dari berbagai kalangan profesi dan usia. Program pelatihan bahasa Inggris tersebut telah memperkenalkan masyarakat Desa Jatijajar kepada bahasa Inggris, oleh karena itu ada peningkatan kemampuan dalam berbahasa Inggris. Masyarakat yang tadinya belum begitu tahu atau tidak bisa berbahasa Inggris, dengan adanya pelatihan tersebut menjadi memiliki kemampuan untuk berbahasa Inggris. Sedangkan masyarakat Desa Jatijajar yang sebelumnya sudah tahu dan bisa berbahasa Inggris menjadi lebih menguasai karena adanya pelatihan tersebut.

Peningkatan kemampuan bahasa Inggris juga tentu saja dialami oleh tutor. Seperti yang dijelaskan, bahwa sebelum mereka menjadi tutor terlebih dahulu dikirim ke Pare, Kediri untuk melakukan pelatihan bahasa Inggris. Dengan adanya pelatihan bahasa Inggris tersebut kemampuan berbahasa Inggris para tutor meningkat pesat sehingga dapat mengajar dan mentransfer ilmunya kepada para peserta pelatihan di KIK.

Peningkatan kemampuan peserta pelatihan dalam berbahasa Inggris setelah melakukan pembelajaran di KIK terlihat dari hasil test yang dilakukan oleh tutor kepada peserta pelatihan. Ada dua macam test yaitu tes sebelum melakukan pembelajaran dan setelah melakukan pembelajaran. Dari test tersebut nilai post test seringkali lebih tinggi dari pada nilai yang diperoleh peserta saat 
pre test hal ini menunjukan adanya peningkatan kemampuan berbahasa Ingggris di KIK.

d) Pola penggunaan bahasa

Masyarakat yang bertempat tinggal di Kampung Inggris Kebumen sudah mengenal penggunaan bahasa Inggris dalam berkomunikasi disamping penggunaan bahasa Indonesia sebagai bahasa nasional dan bahasa Jawa sebagai bahasa daerah yang dipergunakan sehari-hari oleh masyarakat desa.

Tutor dan peserta pelatihan menggunakan bahasa Inggris dalam pembelajaran di kelas. Selain itu penggunaan bahasa Inggris juga digunakan dalam forum informal atau diluar pembelajaran. Tutor dan peserta juga terkadang menggunakan sedikit bahasa Inggris sederhana untuk berkomunikasi dengan masyarakat sekitar, penggunaan bahasa Inggris tersebut misalnya dengan pemilik homestay, ataupun dengan pemilik warung apabila ingin bertanya sesuatu yang sederhana dan biasa digunakan sehari-hari. Oleh karena itu bahasa Inggris telah sedikit demi sedikit digunakan dalam kehidupan sehari-hari masyarakat di KIK meskipun belum secara intens dan menyeluruh.

e) Paguyuban pemilik homestay
Dampak di bidang sosial selanjutnya yang dirasakan warga Desa Jatijajar akibat adanya pembangunan KIK adalah terbentuknya organisasi atau paguyuban para pemilik homestay. Para pemilik homestay mendirikan perkumpulan atau paguyuban tersebut sejak didirikannya Kampung Inggris Kebumen di desa mereka.

Paguyuban para pemilik homestay ini pada setiap perkumpulan tidak hanya beragendakan untuk evaluasi jalannya KIK saja namun juga mengadakan kegiatan arisan setiap 2 minggu sekali, dan mengadakan iuran untuk mengisi kas paguyuban tersebut yang nantinya digunakan untuk berbagai keperluan paguyuban. Hal-hal yang dibahas dalam perkumpulan tersebut antara lain mengenai kegiatan dan proses berlangsungnya 1 batch atau satu periode pembelajaran di KIK, serta mengevaluasi kenyamanan setiap homestay.

f) Kelompok belajar anak

Dalam rangka menggiatkan serta memasyarakatkan bahasa Inggris di Kampung Inggris Kebumen, para tutor memperkenalkan bahasa Inggris kepada anak-anak Desa Jatijajar. Pengenalan tersebut 
dilakukan dengan membentuk tersebut dianggap mengganggu

kelompok belajar bahasa Inggris yang bisa diikuti oleh anak-anak Desa Jatijajar secara gratis. Hal ini dilakukan untuk menarik minat anakanak Desa Jatijajar terhadap bahasa Inggris sehingga bahasa Inggris menjadi bahasa yang nantinya dapat digunakan sebagai bahasa komunikasi di Desa Jatijajar di samping bahasa Indonesia sebagai bahasa nasional dan bahasa Jawa sebagai bahasa daerah untuk tetap dilestarika

g) Kebisingan

Dampak terakhir di bidang sosial yang dirasakan warga berupa dampak negatif bagi sebagian warga Desa Jatijajar akibat adanya pembangunan KIK. Dalam metode pembelajaran di KIK, pembelajaran yang dilakukan menggunakan "Speaking loundly" atau berbicara dengan suara yang lantang. Metode tersebut digunakan untuk merangsang keberanian peserta mempermudah proses menghafal rumus dan suku kata dalam bahasa Inggris.

\section{Penggunaan cara belajar} "speaking loudly" tersebut, peserta pelatihan dalam proses pembelajarannya menghasilkan suara yang keras. Cara pembelajaran dalam hal suara bagi beberapa warga sekitar. Hal ini dikarenakan kelas tempat peserta pelatihan KIK belajar berada di tengah-tengah perkampungan warga serta ada juga yang berada di teras rumah warga yang disewa sebagai kelas.

\section{Simpulan}

Kegiatan Kampung Inggris Kebumen telah membawa perubahan kondisi sosial dan ekonomi di masyarakat Desa Jatijajar. Dampak dalam bidang ekonomi antara lain tumbuhnya lapangan pekerjaan yaitu lapangan pekerjaan untuk menjadi tutor, menjadi pemilik homestay, membuka warung, menerima katering, serta menerima laundry. Dampak ekonomi tersebut telah menguntungkan warga karena dapat menambah penghasilan mereka dan memperbaiki tingkat ekonomi masyarakat sekitar.

Perubahan Kondisi Sosial berupa perubahan status sosial, perubahan interaksi antar warga, munculnya bentuk interaksi baru yang terjalin antara masyarakat dengan peserta pelatihan, masyarakat dengan pengurus $\mathrm{KIK}$, masyarakat dengan tutor dan interaksi antar sesama warga masyarakat. 
perubahan sosial lainnya juga terjadi pada pola penggunaan bahasa dimana bahasa Inggris sudah mulai digiatkan dan digunakan dalam kehidupan sehari-hari ,serta adanya peningkatan kemampuan bahasa Inggris masayarakat Selain itu terbentuknya paguyuban pemilik homestay dan terbentuknya kelompok belajar anak merupakan salah satu dampak sosial lain akibat pembangunan KIK tersebut. Disamping dampak positif, ada juga dampak negatif yang dirasakan masyarakat dampak negatif tersebut berupa kebisingan, serta tidak meratanya partisipasi masyarakat sehingga masih ada masyarakat yang menerima banyak keuntungan dari adanya KIK namun sebagian lainnya masih belum menerima manfaat adanya KIK.

\section{Ucapan Terimakasih}

Terimakasih disampaikan

kepada Bapak Prof. Dr. Sutrisna Wibawa, M.Pd., selaku Rektor Universitas Negeri Yogyakarta, Ibu V. Indah Sri Pinasti, M.Si., selaku pembimbing, Seluruh Dosen Pendidikan Sosiologi, BAPPEDA Kabupaten Kebumen, Desa Jatijajar, Kampung Inggris Kebumen dan instansi terkait lainnya, Masyarakat
Desa Jatijajar, Kepala Desa Jatijajar dan segenap pengurus Kampung Inggris Kebumen serta tim redaksi Jurnal Pendidikan Sosiologi fakultas ilmu Sosial UNY yang telah mempublikasikan hasil karya ini.

\section{Daftar Pustaka}

Adisasmita, R. (2013). Teori-Teori Pembangunan Ekomoni: Pertumbuhan Ekonomi dan Pertumbuhan Wilayah. Yogyakarta: Graha IImu.

Alhumami, A. (2009). Evolusi Pemikiran Pembangunan. Bappenas Website. https://www.bappenas.go.id/fil e/3513/4986/4364/05amich_2 0091014125824_2251_0.pdf. Diakses pada 22 Januari 2018.

Ali, f., \& Alam, A. S. (2012). Studi Kebijakan Pemerintah. Bandung: Refika Aditama.

Hatu, R. A. (2013). Sosiologi Pembangunan. Gorontalo: Interpena.

Indraddin, I. (2016). Strategi dan Perubahan Sosial

Yogyakarta: Deepublish.

Jamaludin, A. N. (2016). Sosiologi Pembangunan . Bandung: Pustaka Setia.

Soekanto, S. (2013). Sosiologi Suatu Pengantar. Jakarta: Rajawali Pers.

Sugiarto, E. (2015). Menyusun Proposal penelitian Kualitatif: Skripsi dan Tesis. Yogyakarta: Suaka Media.

Sugiyono. (2007). Metode Penelitian Pendidikan (Pendekatan Kualitatif, Kuantitatif dan $R \& D)$. Bandung: Alfabeta.

Syahrial Syarbaini, F. (2016). Teori Sosiologi Suatu Pengantar. 
Bogor: Penerbit Ghalia

Indonesia.

Usman, S. (2015). Esai-Esai Sosiologi- Perubahan Sosial. Yogyakarta: Pustaka Pelajar.

Zuhal. (2008). Kekuatan Daya Saing Indonesia: Mempersiapkan Masyarakat Berbasis IImu Pengetahuan. Jakarta: Kompas.

https://id.m.wikipedia.org/wiki/Otono mi daerah/ Diakses pada 12 Februari 2018

http://jdih.kebumenkab.go.id/produkh ukum/ Diakses pada 2 Agustus 2018 